УДК 339.92

\title{
МІЖНАРОДНА КООРДИНАЦІЯ СТРАТЕГІЙ ІНТЕГРАЦІЇ В'ЄТНАМУ ДО СВІТОВОГО ЕНЕРГЕТИЧНОГО РИНКУ ЗГІДНО З ВИМОГАМИ СТАЛОГО РОЗВИТКУ
}

\author{
INTERNATIONAL COORDINATION \\ OF VIETNAM'S INTEGRATION STRATEGIES \\ TO THE WORLD ENERGY MARKET UNDER \\ THE REQUIREMENTS OF SUSTAINABLE DEVELOPMENT
}

\author{
Гальперіна Любов Павлівна \\ кандидат економічних наук, профресор, \\ ДВНЗ «Київський національний економічний університет \\ імені Вадима Гетьмана» \\ ORCID: https://orcid.org/0000-0002-2452-2853 \\ Панченко Євген Григорович \\ доктор економічних наук, профресор, \\ ДВНЗ «Київський національний економічний університет \\ імені Вадима Гетьмана» \\ ORCID: https://orcid.org/0000-0002-8650-8029 \\ Яценко Ольга Миколаївна \\ доктор економічних наук, профессор, \\ ДВНЗ «Київський національний економічний університет \\ імені Вадима Гетьмана» \\ ORCID: https://orcid.org/0000-0003-4399-2217
}

Galperina Liubov, Panchenko Yevhen, Yatsenko Olga

Kyiv National Economic University named after Vadym Hetman

\footnotetext{
Стаття присвячена впливу міжнародної координації стратегій інтеграції енергетичної системи В'єтнаму до світового енергетичного ринку згідно вимог сталого розвитку. Визначено, що енергетика В'єтнаму прискореними темпами інтегрується у світовий енергетичний ринок. Участь у міжнародній координації щодо імплементації вимог сталого розвитку спричинила коригування енергетичних стратегій В'єтнаму в бік зміни структури первинного енергоспоживання. На стратегії інтеграції В'єтнаму до світового енергетичного ринку вплинула участь у міжнародній координації з приводу сталого розвитку енергетики на всіх рівнях: на першому - при обміні інформацією щодо вимог та заходів сталого розвитку на глобальному, регіональному та національному та локальному рівнях; на другому - бере до уваги плани щодо сталого розвитку енергетики інших країн в національні енергетичні плани та стратегії; на третьому - здійснює спільні дії за для досягнення цілей сталого розвитку в рамках АСЕАН.

Ключові слова: міжнародна координація, світовий енергетичний ринок, зовнішня торгівля, енергетика, стратегія, сталий розвиток, В'єтнам, АСЕАН.

Статья посвящена влиянию международной координации стратегий интеграции энергетической системы Вьетнама в мировой энергетический рынок в соответствии с требованиями устойчивого развития. Определено, что энергетика Вьетнама ускоренными темпами интегрируется в мировой энергетический рынок. Участие в международной координации по имплементации требований устойчивого развития вызвала корректировки стратегий Вьетнама в сторону изменения структуры первичного энергопотребления. Вьетнам участвует в международной координации по поводу устойчивого развития энергетики на таких уровнях: на первом - при обмене инорормацией относительно требований и мер устойчивого развития на глобальном, региональном и национальном и локальном уровнях; на втором - принимает во внимание планы устойчивого развития энергетики других стран в национальные энергетические планы и
} 
стратегии; на третьем - осуществляет совместные действия по для достижения целей устойчивого развития в рамках АCEAH.

Ключевые слова: международная координация, мировой энергетический рынок, внешняя торговля, энергетика, стратегия, устойчивое развитие, Вьетнам, АСЕАН.

The article focuses on the impact of international coordination of strategies for the integration of Vietnam's energy system into the global energy market, taking into account the requirements of sustainable development. It is determined that the energy sector of Vietnam is rapidly integrating into the world energy market, which is manifested in increased foreign trade in fuel and energy resources, attracting foreign investors in large-scale energy projects, increasing the presence of national TNCs in the national market. Vietnam is expanding the geographical structure of energy partnerships in the region and beyond Southeast Asia, strengthening regional energy cooperation within ASEAN. The role of international coordination in the implementation of sustainable development requirements in the process of integration of Vietnamese energy into the world energy market has been identified. The implementation of sustainable development requirements into national energy policy and participation in international coordination to combat climate change has led to an adjustment of Vietnam's energy strategies to change the structure of primary energy consumption by reducing the share of coal and oil in electricity generation in favor of natural gas and renewable energy sources. government strategies of new increased key indicators for increasing the share of renewable energy sources. Vietnam's government strategies set new high key indicators for increasing the share of renewable energy. Vietnam participates in international coordination on sustainable energy development at all levels: at the first - in the exchange of information on requirements and measures for sustainable development at the global, regional and national, and local levels; on the second, it takes into account plans for sustainable energy development of other countries into national energy plans and strategies ASEAN Plan of Action for Energy Cooperation (APAEC). This plan contributes to the direction of energy strategies of all member countries to improve energy security, the sustainable future energy landscape of ASEAN, and the integration of the group into the global energy market. Vietnam's energy integration strategies are coordinated with ASEAN's sustainable energy development strategies for the modernization of electricity networks and the functioning of the regional electricity market; on joint development of ASEAN gas market infrastructure; on the implementation of "clean coal" technology; on the implementation of measures and standards of energy efficiency and energy saving; to increase the share of renewable energy; on compliance of regional energy policy and planning with global trends; on cooperation with international organizations and the best operators in the use of nuclear energy for peaceful purposes); on the third - carries out joint actions to achieve the goals of sustainable development (ASEAN Petroleum Security Agreement APSA), participation in the development of a common infrastructure of the regional gas and electricity market).

Keywords: international coordination, world energy market, foreign trade, energy, strategy, sustainable development, Vietnam, ASEAN.

Постановка проблеми. В умовах загострення глобальних проблем людства, зокрема, тих, які виникають при взаємодії людини і суспільства, економіки і природи, актуалізуються спільні зусилля щодо їх вирішення. Міжнародна координація соціальноекономічних, геоекономічних та безпекових стратегій країн світу сприяє їх узгодженості 3 вимогами сталого розвитку на рівні реалізації в межах національних юрисдикцій та при інтеграції до світового господарства. Специфріка природних умов В'єтнаму, який зазнає негативних наслідків від змін клімату, пошук балансу між проведенням ринкових ресрорм та соціалістичними ідеями, надмірне навантаження на навколишнє природнє середовище внаслідок прискореного економічного розвитку обумовили потребу узгоджувати соціально-економічну політику 3 вимогами сталого розвитку.

Особливого значення набуває прагнення країни досягти вимог сталого розвитку. Енергетична система В'єтнаму та її інтеграція до світового енергетичного ринку знаходиться під особливим контролем з боку держави, однак зазнає прямого чи опосередкованого впливу міжнародних координаційних механізмів. Тематика дослідження впливу координаційних зусиль на макрорегіональному та глобальному рівні на адаптацію до вимог сталого розвитку стратегій В'єтнаму щодо інтеграції до світового енергетичного ринку вбачається актуальною $з$ точки зору теорії та практики міжнародних економічних відносин.

Аналіз останніх досліджень і публікацій. Найвища активність наукових досліджень впливу, ефективності та доцільності міжнародної координації припадала на період, що слідував за найбільшою хвилею деколонізації. Сучасна криза наднаціональних інституцій мотивує досліджувати міжнародні та глобальні інституційні засади щодо координації 3 точки зору їх здатності вирішувати сучасні глобальні проблеми. Всеосяжна роль Резолюції $\mathrm{OOH}$ «Трансорормація нашого світу: Порядок денний в галузі сталого розвитку на період до 2030 року» [1] обумовлює актуальність досліджень концепцій її імплементації в країнах [2] 
зурахуванням різнихаспектів конкурентоспроможності, міжнародної економічної [3], perioнальної в АСЕАН [4] та національної енергетичної безпеки [5] тощо. Широко представлені дослідження сучасних трендів в енергетиці на світовому [6; 7] та регіональному ринку Південно-Східної Азії [8; 9], у тому числі в рамках ACEAH [10]. Трансфрормацію та модернізацію на національних енергетичних ринках 3 урахуванням вимог сталого розвитку у контексті їх конвергенції до міжнародних енергетичних систем досліджено в працях [11; 12]. Разом 3 тим, лише одиничні роботи вітчизняних авторів [13] та нечисленні - іноземних [14; 15] присвячені в'єтнамській енергетиці та її інтеграції до світового енергетичного ринку у відповідності з вимогами сталого розвитку та з урахуванням міжнародної координації [16].

Виділення невирішених раніше частин загальної проблеми. Проблематика дослідження міжнародної координації відповідності національних стратегій вимогам сталого розвитку актуальна сама по собі. Особливої ваги набуває координація стратегій інтеграції національної енергетики до світового енергетичного ринку оскільки енергетика робить значний внесок як у забезпечення сталого розвитку, так і у забруднення навколишнього середовища. Цілепокладання на вимоги сталого розвитку щодо інтеграції до світового енергетичного ринку В'єтнаму недостатньо досліджене, у тому числі щодо впливу міжнародної координації.
Формулювання цілей статті (постановка завдання). Метою статті визначено дослідження впливу міжнародної координації стратегій інтеграції енергетичної системи В'єтнаму до світового енергетичного ринку 3 урахуванням вимог сталого розвитку.

Виклад основного матеріалу дослідження. Інтеграція В'єтнаму у світове господарство відбувається після десятиріччя економічної самоізоляції 1976-1986 років поетапно, з урахуванням національної безпеки та конкурентоспроможності окремих галузей та секторів народного господарства. В'єтнам володіє значними доведеними запасами вуглеводнів. За величиною запасів насти (4,4 млрд барелів) країна займає перше місце в Південно-Східній Азії, третє місце Азіатсько-Тихоокеанському регіоні (АТР) після Китаю та Індії, шосте місце - за величиною запасів природного газу $\left(0,6\right.$ трлн м $\left.^{3}\right)$ та вугілля (3,36 млрд тонн). За величиною запасів насрти В'єтнам займає 25-те місце в світі (за даними ВР [17]). У загальносвітовому вимірі доведені запаси вуглеводнів В'єтнаму станом на кінець 2019 року не перевищують частку 0,32\% (табл. 1).

Прискорене економічне зростання країни (темп приросту протягом останніх тридцяти років не опускався нижче $5,1 \%$, а у 2018-2019 роках 7,1-7,0\% [18]), політика індустріалізації, зростання добробуту та стимулювання експорту спричинили зростання

Таблиця 1

Географічна структура доведених запасів вуглеводнів Азіатсько-Тихоокеанського регіону, 2019 рік, частка світових запасів, \%

\begin{tabular}{|l|c|c|c|}
\hline \multicolumn{1}{|c|}{ Країни } & Нафта & Природний газ & Вугілля \\
\hline Світ & 100 & 100 & 100 \\
\hline Азіатсько-Тихоокеанський регіон & 2,64 & 8,88 & 42,71 \\
\hline Китай & 1,51 & 4,23 & 13,24 \\
\hline Індія & 0,27 & 0,67 & 9,90 \\
\hline В'єтнам & 0,25 & 0,32 & 0,31 \\
\hline Малайзія & 0,16 & 0,48 & - \\
\hline Індонезія & 0,14 & 0,72 & 3,73 \\
\hline Австралія & 0,14 & 1,2 & 13,94 \\
\hline Бруней & 0,06 & 0,12 & - \\
\hline Таїланд & 0,1 & 0,09 & - \\
\hline Бангладеш & - & 0,06 & - \\
\hline Пакистан & - & - & 0,24 \\
\hline Монголія & - & - & 0,71 \\
\hline Нова Зеландія & - & - & 0,19 \\
\hline $\begin{array}{l}\text { Інші країни Азіатсько- } \\
\text { Тихоокеанського регіону }\end{array}$ & 0,08 & 0,12 & \\
\hline
\end{tabular}


первинного споживання енергоресурсів, яке перевищує обсяги пропозиції, що виявило проблеми енергетичної безпеки, які вирішуються як на рівні країни, так і завдяки співпраці з зовнішніми контрагентами.

В'єтнам має добровільні зобов'язання щодо сталого розвитку енергетики в рамках міжнародної координації на глобальному рівні національних цілей та задач з орієнтирами Резолюції ООН «Перетворення нашого світу: Порядок денний у сорері сталого розвитку до 2030 року» (2015) та як підписант Паризької кліматичної угоди (2015) Конференції ООН 3 проблем клімату (СОР21). Участь країни в регіональному інтеграційному об'єднанні країн Південно-Східної Азії АСЕАН передбачає міжнародну координацію енергетичних політик на різних ієрархічних рівнях щодо імплементації вимог сталого розвитку. Так, в рамках АCEAH реалізовується міжнародна координація на першому ієрархічному рівні (обмін інформацією) в рамках Енергетичного бізнес-фроруму ACEAH (ASEAN Energy Business Forum (AEBF)), який поєднується в часі $з$ щорічним засіданням міністрів АCEAH 3 питань енергетики (AMEM), на якому реалізовується другий та третій рівень міжнародної координації - врахування планів інших країн та узгодження енергетичної політики країнчленів. Також до другого рівня міжнародної координації можна віднести розроблення та впровадження в межах Ради 3 нафти АCEAH (ASEAN Council on Petroleum (ASCOPE)) y 2015 році операторами нафто- та газовидобутку в країнах-членах АCEAH Керівництва 3 виведення з експлуатації ASCOPE для нафртових і газових споруд (ADG) для запланованої діяльності (тобто не передбачено його використання при фрорс-мажорних обставинах, аварійній ситуації тощо) [19]. Дане керівництво $€$ прикладом інструменту міжнародної координації, оскільки враховує сучасні технології та особливості країн АСЕАН, розроблене згідно міжнародного законодавства, у тому числі глобальних та регіональних конвенцій з охорони навколишнього природного середовища, техногенної безпеки, резолюції ООН щодо сталого розвитку, не протирічить національному законодавству всіх країн-членів. Важливим кроком для застосування даного Керівництва вбачається його узгодження та схвалення всіма наявними національними нафтовими компаніями, у тому числі в'єтнамською вертикально інтегрованою нафрто-газовою компанією PetroVietnam, яка володіє всіма насрто-газовими родовищами
В'єтнаму. Величезний досвід та авторитет як стабільного партнера державної компанії PetroVietnam (заснована у 1977 році) став у нагоді для участі компанії у геолого-розвідувальних роботах та нафртовидобутку в країнах регіону та поза межами Південно-Східної Азії.

У зв'язку з активізацією співпраці В'єтнаму 3 міжнародними компаніями (ExxonMobil, Chevron, BP, Korean National Oil Corporation, Зарубежнефть, NGC Videsh Ltd., спільні Cuu Long Joint Operating Company (CLJOC), ConocoPhillips Vietnam, Japan Vietnam Petroleum та ін.) на локальному, загальнонаціональному, регіональному та світовому ринках в нагоді стає участь у міжнародній координації на другому рівні щодо мінімально допустимих вимог з безпеки праці, техногенної, енергетичної безпеки та охорони навколишнього природного середовища для місцевих громад, які висуваються по відношенню до насртогазових компаній працюючих в АСЕАН у «Керівних принципах системи управління ASCOPE HSSE» [19].

В'єтнам долучений до другого рівня міжнародної координації енергетичної політики також шляхом активної участі у діяльності центрів та закладів у структурі АCEAН, наприклад, Центру енергетики АСЕАН, Ради 3 нафрти ACEAН та ін. Центр енергетики АСЕАН приймає Плани дій АСЕАН з енергетичного співробітництва (APAEC) сприяє спрямованню енергетичних стратегій усіх країн-членів підвищенню енергобезпеки, сталого майбутнього енергетичного ландшафрту ACEAH та інтеграції угруповання у світовий енергетичний ринок. Зокрема, стратегії інтеграції енергетики В'єтнаму координуються зі стратегіями сталого розвитку енергетики АCEAH щодо модернізації електричних мереж та срункціонування регіонального ринку електроенергії; щодо спільної розбудови інфрраструктури газового ринку АСЕАН; щодо імплементації технології «чистого вугілля», щодо впровадження заходів та стандартів енергоефективності та енергозбереження; щодо підвищення питомої ваги відновлюваної енергетики; щодо відповідності регіональної енергетичної політики та планування світовим трендам; щодо співпраці 3 міжнародними організаціями та кращими операторами з використання ядерної енергетики в мирних цілях.

Важливим суб'єктом третього рівня міжнародної координації енергетичних політик виступає ратифікована всіма державами-членами Нова Угода про насттову безпеку АCEAH (APSA), яка встановлює схему перерозподілу насрти в якості надання допомоги державам- 
членам під час надзвичайних ситуацій через дефіцит постачання насрти [22]. Іншим важливим кроком до сталого розвитку $\epsilon$ участь В'єтнаму у розбудові спільної інфрраструктури регіонального ринку газу та електроенергії ACEAН, що відноситься до третього рівня міжнародної координації.

В'єтнам різною мірою залучений до світового та регіонального енергетичного ринку. Частка В'єтнаму у на світовому ринку мінерального палива та електроенергії зростає 3 2015 до 2019 років, при цьому частка експорту зросла в 2,3 рази, але не перевищувала про- тягом десятиліття 2010-2019 років питомої ваги у 0,7\%, а імпорту, навпаки, - скоротилась в 1,5 рази (рис. 1).

Інша динаміка спостерігається щодо частки В'єтнаму в експорті та імпорті мінерального палива та електроенергії агрегованих даних країн АСЕАН. За той же період частка в'єтнамського експорту скоротилась 3 $4,8 \%$ до $2,6 \%$ (з максимумом у 2012 році 5\% та мінімумом у 2018 році $2,4 \%)$. У той час як частка імпорту коливалась і досягла максимуму 3,4\% у 2016-2017 роках 3 подальшим зниженням до 2,3\% у 2019 році (рис. 2).

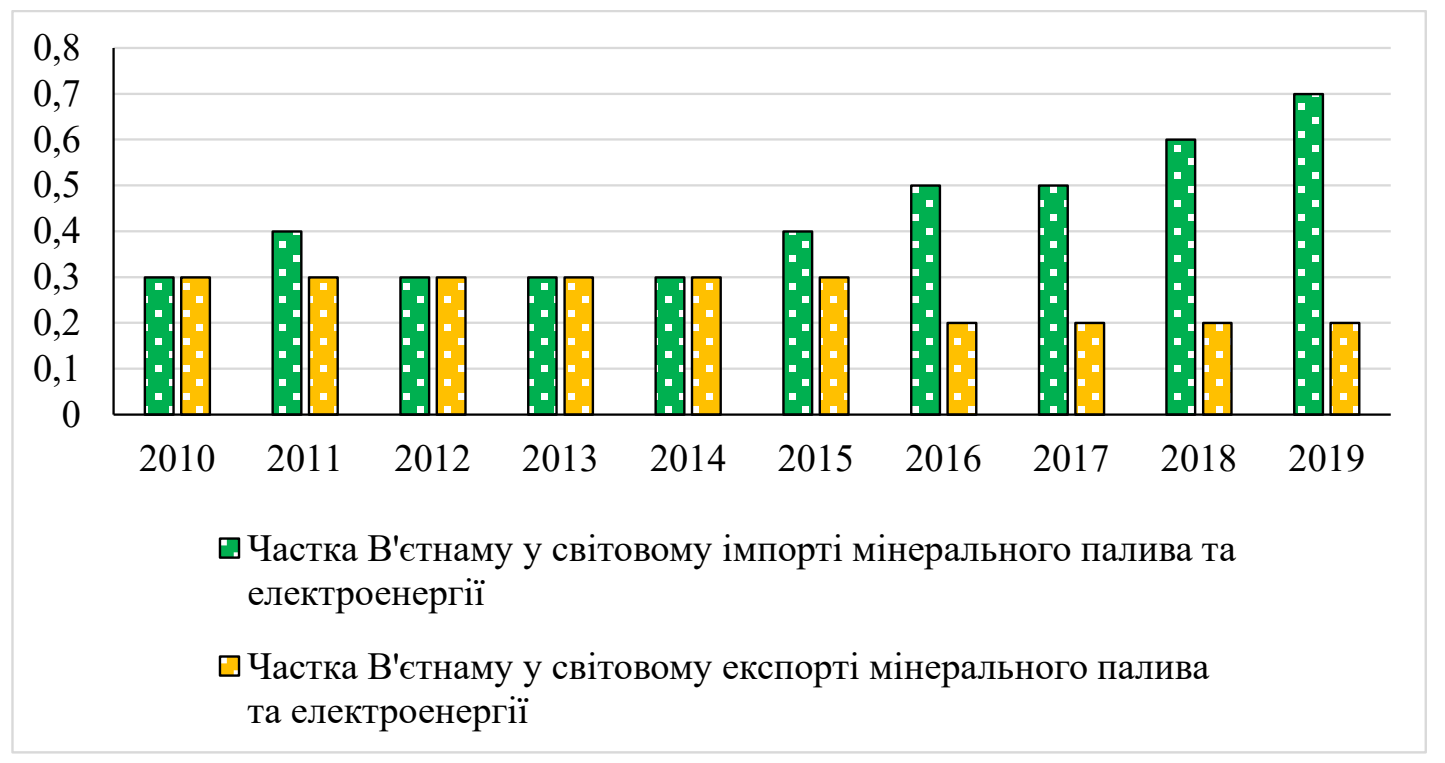

Рис. 1. Динаміка частки В'єтнаму у світовому експорті та імпорті мінерального палива та електроенергії, 2010-2019, \%

Джерело: розраховано та побудовано за даними [20]

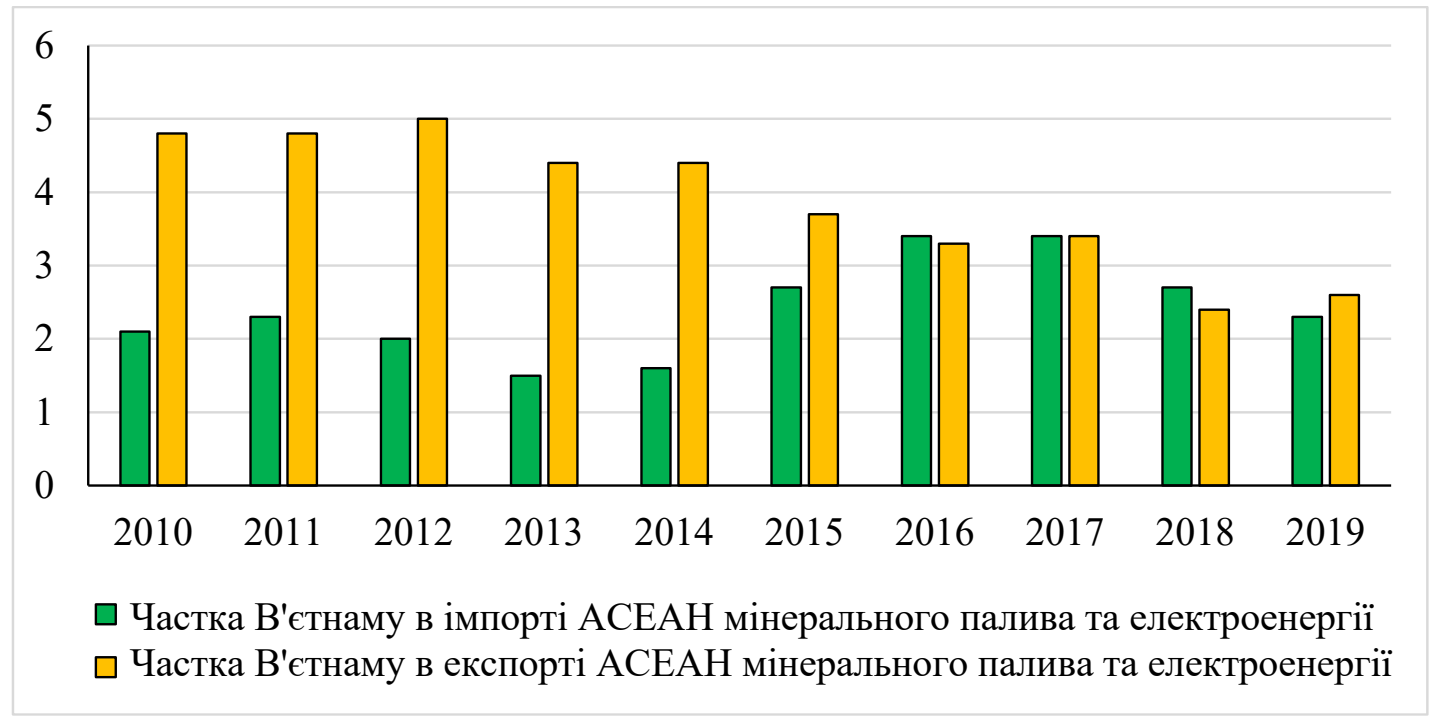

Рис. 2. Динаміка частки В'єтнаму експорті та імпорті мінерального палива та електроенергії АСЕАН, 2010-2019, \%

Джерело: розраховано та побудовано за даними [20] 
Зростаючі потреби національної економіки в енергоресурсах у поєднанні з недостатніми інвестиціями у розвідку та видобуток спричинили скорочення загальної вартості експорту викопного палива та електроенергії В'єтнаму ще до падіння світових насртових цін у 2014 році та зниження світового попиту енергоресурсів внаслідок пандемії Covd19. У структурі експорту питома вага настти скоротилась з 22\% у 2005 році до 0,7\% у 2019 році, експорт інших видів викопного палива та електроенергії не справляв суттєвого значення на економіку країни. В паливно-енергетичному експорті В'єтнаму простежується тенденція зростання питомої ваги імпортних ринків країн АСЕАН з 32\% у 2010 році до 47\% у 2019 році (рис. 3).

Знову ж таки, зростання потреб економіки та суспільства в енергоресурсах 3 однієї сторони, вичерпання природних можливостей подальшого розвитку гідроенергетики, яка складає основу національного енергобалансу, та недостатнє використання потенціалу власних покладів спричинило зростання імпорту викопного палива та електроенергії у вартісному вимірі. Відмітимо зменшення ролі ACEAH у структурі зовнішніх постачальників паливо-енергетичних ресурсів: у 2010 р. їх частка складала 44\%, у 2016 році - 59\%, у 2018-2019 - 31\% (рис. 4). Серед країн, які експортують до В'єтнаму енергоресурси представлені всі макрорегіони світу, але Топ10 постачальників енергоресурсів складають такі країни: Кувейт, Південна Корея, Китай, Австралія, Малайзія, Сінгапур, Індонезія, Російська Федерація, Таїланд, Канада.

Серед постачальників до В'єтнаму сирої насрти у 2018-2019 роках лідирує Кувейт (85,4\% та 91,8\%), постачання важкої нафти 3 якого розпочалось тільки у 2017 р. 3 194,4 млн дол. США, що складало 30\% експорту В'єтнамом нафти. Кувейт вийшов на в'єтнамський ринок завдяки 35,1\% участі у міжнародному консорціумі з будівництва та експлуатації другого за часом, але першого за потужністю нафтопереробного заводу Nghi Son Refinery. Даний інвестиційний проект найбільший у В'єтнамі за вартістю залучення іноземних інвесторів з Кувейту, Японії, Малайзії, Південної Кореї та Франції (9 млрд дол. США, з яких 4 млрд. дол. США - спонсорські кошти). Нафтопереробний завод хоч і належить до переробки вуглецевих джерел, відповідає вимогам основних засад сталого розвитку в енергетиці: забезпечення внутрішнього ринку власним дизельним та реактивним паливом покращує енергобезпеку країни та доступ населення до енергоресурсів, наявність очисних споруд мінімізує шкідливий вплив, значна глибина переробки 3 отриманням

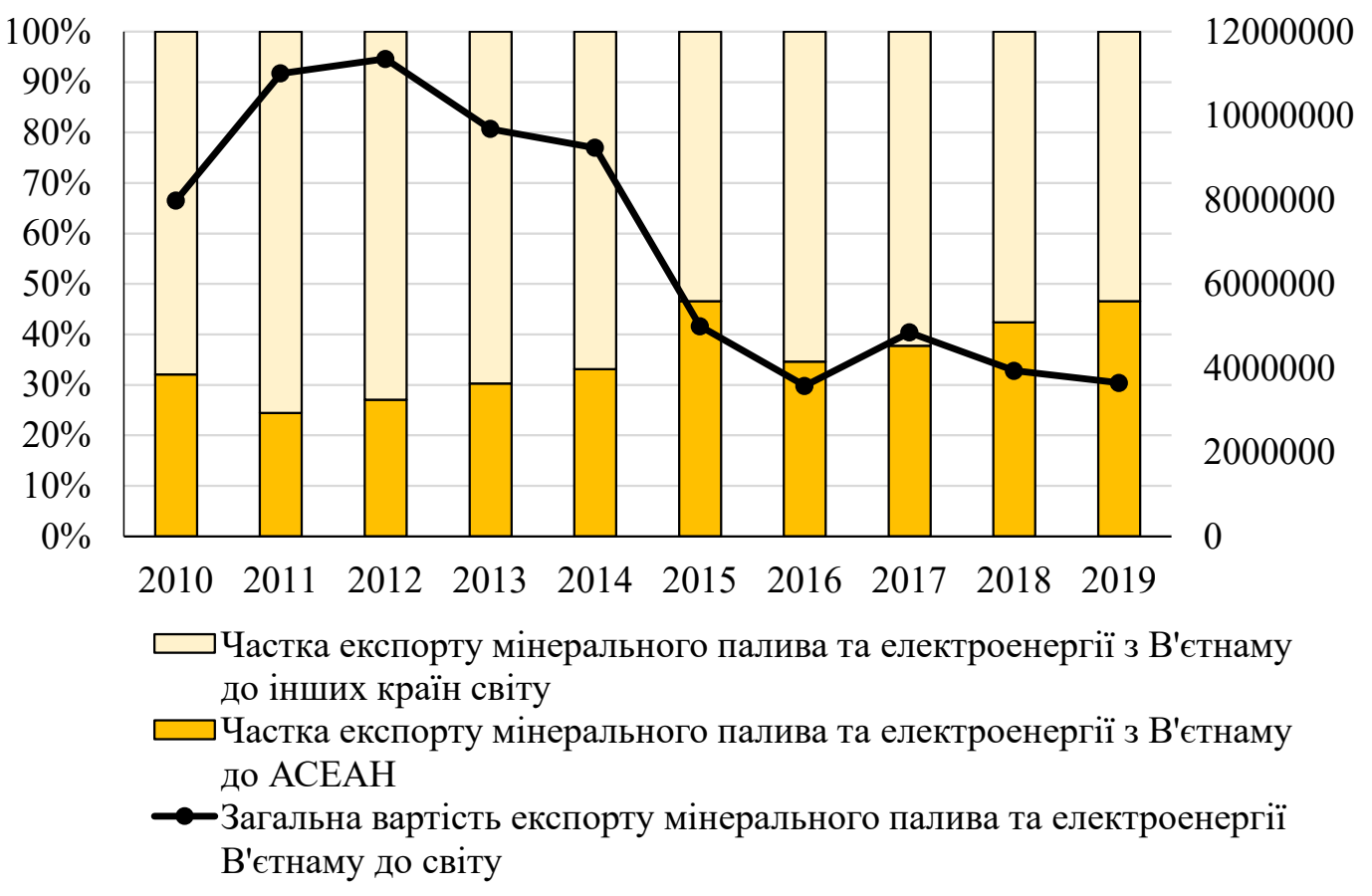

Рис. 3. Динаміка експорту мінерального палива та електроенергії з В'єтнаму до країн світу та АСЕАН, 2010-2019, \% (ліва шкала), тис. доларів США (права шкала) Джерело: розраховано та побудовано за даними [20] 


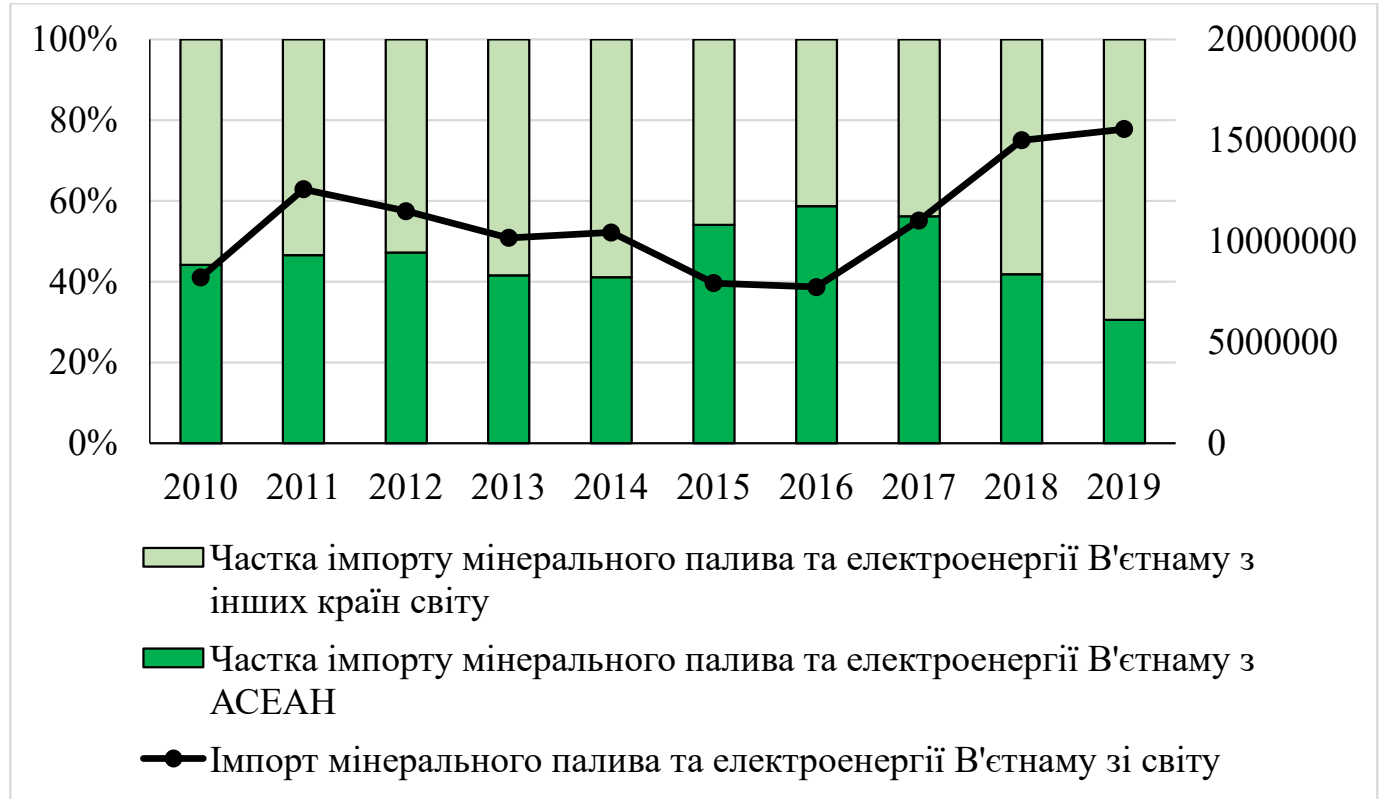

Рис. 4. Динаміка імпорту мінерального палива та електроенергії з країн світу та АСЕАН до В'єтнаму, 2010-2019, \% (ліва шкала), тис. доларів США (права шкала)

Джерело: розраховано та побудовано за даними [20]

нафртохімічних продуктів з високою доданою вартістю сприяє ефрективності використання насрти, створення нових робочих місць підвищує добробут. Ефект проекту полягає також у тому, що підприємство реалізовує продукцію з більшою доданою вартістю ніж реалізація сирої насти на експорт.

На другому місці серед постачальників мінерального палива - Південна Корея (13,3\%, 31\% - продукція нафртопереробки). На третьому Китай з часткою паливно-енергетичного експорту у $11,5 \%$ (серед яких і продукція нафртопереробки, газ, і коксівне та паливне вугілля, і електроенергія).

Важливим напрямом інтеграції В'єтнаму до світового енергетичного ринку відповідно до вимог сталого розвитку став розвиток відновлюваної енергетики (сонячної та вітрової) протягом 2017-2020 років. Було розпочато будівництво 124 нових сонячних, 73 вітрових та семи біо-електростанцій. Як результат даних рішень створені нові робочі місця та чисельність зайнятих у цьому секторі В'єтнамської економіки досягла у сонячній енергетиці 56,8 , у біопаливній 2,67, у вітровій 2,1 тис осіб у 2019 році [21]. Саме імплементація вимог сталого розвитку в національну енергетичну політику та участь у міжнародній координації щодо боротьби зі змінами клімату спричинила коригування енергетичних стратегій В'єтнаму в бік зміни структури первинного енергоспоживання шляхом зменшення частки вугілля та нафти в електрогенерації на користь природного газу та відновлюваних джерел енергії із закріпленням в урядових енергетичних стратегіях нових підвищених ключових показників щодо зростання частки відновлюваних джерел енергії [13]. Цій меті сприяє міжнародна координація першого рівня (обмін інформацією) 3 міжнародними організаціями та регіональними угрупованнями (наприклад, $€ C)$ з приводу отримання нових енергетичних технологій та модернізації енегросистеми.

Висновки. Енергетика В'єтнаму прискореними темпами інтегрується у світовий енергетичний ринок, це має прояв у збільшенні зовнішньоторгівельного обороту паливно-енергетичними ресурсами, залученні іноземних інвесторів у реалізацію масштабних енергетичних проєктів, збільшення присутності на національному ринку енергетичних ТНК, розширенні географрічної структури партнерів у сорері енергетики в регіоні та поза межами Південно-Східної Азії, посиленні регіонального енергетичного співробітництва в рамках АСЕАН. Визначено зростання ролі міжнародної координації у імплементації вимог сталого розвитку в процесі інтеграції в'єтнамської енергетики у світовий енергетичний ринок. На стратегії інтеграції В'єтнаму до світового енергетичного ринку вплинула участь у міжнародній координації з приводу сталого розвитку енергетики на таких рівнях: на першому - при 
обміні інсрормацією щодо вимог та заходів сталого розвитку на глобальному, регіональному та національному та локальному рівнях; на другому - бере до уваги плани щодо сталого розвитку енергетики інших країн в національні енергетичні плани та стратегії (в рамках Плану дій АCEAН з енергетичного співробітництва (АРАЕС) відкоригував енергетичну стратегію у напрямку підвищення енергобезпеки, сталого майбутнього та інтеграції у світовий енергетичний ринок згідно вимог сталого розвитку).

\section{СПИСОК ВИКОРИСТАНИХ ДЖЕРЕЛ:}

1. Transforming our world: the 2030 Agenda for Sustainable Development. Available at: https://www.un.org/ga/ search/view_doc.asp?symbol=A/RES/70/1\&Lang=E

2. Galperina, L.P., Girenko, A.T., Mazurenko, V.P. (2016). The Concept of Smart Economy as the Basis for Sustainable Development of Ukraine. International Journal of Economics and Financial Issues (IJEFI). Vol 6. No. 8 S (2016). 307-314.

3. Osaulenko O., Yatsenko O., Reznikova N., Rusak D., Nitsenko V. The productive capacity of countries through the prism of sustainable development goals: challenges to international economic security and to competitiveness. Financial and credit activity: problems of theory and practice. Vol 2. No 33. 2020. P. 492-499. doi: 10.18371/fcaptp. v2i33.207214

4. Tongsopit, S., Kittner, N., Chang, Y., Aksornkij, A., \& Wangjiraniran, W. (2016). Energy security in ASEAN: A quantitative approach for sustainable energy policy. Energy policy, 90, 60-72. doi: 10.1016/j.enpol.2015.11.019

5. Фіцілонго Н., Де Паскалє Ж., Теплюк М. А., Зубко Є. В. Передумови розробки інноваційної екосистеми забезпечення енергетичної безпеки країни. Вчені записки. 2019. № 20. С. 29-39. doi: 10.33111/vz_kneu.20.19.01. 03.019.025

6. Рудьковский С.М. Сучасні детермінанти транссоормації світового енергетичного ринку. Стратегія розвитку України. 2018. № 2. С. 147-153.

7. Galperina, L.P., Klen, Yu.V. (2017). Global trends of mergers and acquisitions in the energy sector. International economic policy. 1(26): 46-71.

8. Mamat, R., Sani, M. S. M., \& Sudhakar, K. (2019). Renewable energy in Southeast Asia: Policies and recommendations. Science of the total environment, 670, 1095-1102.

9. Fulton, L., Mejia, A., Arioli, M., Dematera, K., \& Lah, O. (2017). Climate change mitigation pathways for Southeast Asia: CO2 emissions reduction policies for the energy and transport sectors. Sustainability, 9(7), 1160.

10.Behera, S. R., \& Dash, D. P. (2017). The effect of urbanization, energy consumption, and foreign direct investment on the carbon dioxide emission in the SSEA (South and Southeast Asian) region. Renewable and Sustainable Energy Reviews, 70, 96-106.

11. Дроботюк О.В., Осадчук В.Є., Шайдецька В.О. Енергетична трансформація в Китаї: шлях до глобального лідерства у альтернативній енергетиці. Китаєзнавчі дослідження. 2020. № 1. С. 17-26.

12. Панченко Є.Г. Модернізація української газотранспортної системи: національні та міжнародні виклики. Економіка України. 2018. № 10(683). С. 110-126.

13. Kolechko D. Strategic Restructuring of Vietnam's Energy: Compliance with Global Trends. Sciences of Europe. 2020. № 57/57. Vol. 2. Pp. 21-26.

14. Tran Q. M. (2019). Projection of fossil fuel demands in Vietnam to 2050 and climate change implications. Asia \& the Pacific Policy Studies, 6(2), 208-221.

15. Shem, C. et al. (2019). Potentials and opportunities for low carbon energy transition in Vietnam: A policy analysis. Energy Policy. 134: 110818.

16. Nguyen, H. T., Turksen, U. (2019). The External Effects of the Energy Union Strategy on Trade and Investment in Renewable Energy from the EU to Vietnam: an Initial Assessment. Oil, Gas and Energy Law. Vol. (In-press), 30 p.

17. BP. Statistical Review of World Energy June 2020. Available at: http://www.bp.com/statisticalreview

18. World Bank. Available at: https://data.worldbank.org/country/vietnam

19. ASCOPE. Available at: http://www.ascope.org

20. Trade Map. Available at: https://www.trademap.org/lndex.aspx

21. The International Renewable Energy Agency (IRENA) (2020). Available at: https://www.irena.org/Statistics

22. The Association of Southeast Asian Nations. Available at: https://asean.org/ 


\section{REFERENCES:}

1. Transforming our world: the 2030 Agenda for Sustainable Development. Available at: https://www.un.org/ga/ search/view_doc.asp?symbol=A/RES/70/1\&Lang=E

2. Galperina, L.P., Girenko, A.T., \& Mazurenko, V.P. (2016). The Concept of Smart Economy as the Basis for Sustainable Development of Ukraine. International Journal of Economics and Financial Issues (IJEFI), vol. 6, no. 8S (2016), 307-314. Available at: http://www.econjournals.com/index.php/ijefi/article/view/3757

3. Osaulenko O., Yatsenko O., Reznikova N., Rusak D., \& Nitsenko V. (2020). The productive capacity of countries through the prism of sustainable development goals: challenges to international economic security and to competitiveness. Financial and credit activity: problems of theory and practice, vol. 2, no. 33, pp. 492-499. doi: 10.18371/fcaptp.v2i33.207214

4. Tongsopit, S., Kittner, N., Chang, Y., Aksornkij, A., \& Wangjiraniran, W. (2016). Energy security in ASEAN: A quantitative approach for sustainable energy policy. Energy policy, 90, 60-72. doi: 10.1016/j.enpol.2015.11.019

5. Faccilongo, N., Gianluigi De Pascale, Tepliuk M., \& Zubko Y. (2019). Prerequisites for Innovative Ecosystem Development of Country's Energy Security. Scientific Notes, 20: 29-39. doi: 10.33111/vz_kneu.20.19.01.03.019.025 (in Ukrainian)

Rudkovsky, S.M. (2018). Modern Determinants of the Transformation of the World Energy Market. Development strategy of Ukraine, 2: 147-153. Available at: http://jrnl.nau.edu.ua/index.php/SR/article/view/14166 (in Ukrainian)

6. Galperina, L.P., Klen, Yu.V. (2017). Global trends of mergers and acquisitions in the energy sector. International economic policy, 1(26): 46-71. Available at: http://iepjournal.com/journals_eng/26/2017_3_Galperina_Klen.pdf

7. Mamat, R., Sani, M. S. M., \& Sudhakar, K. (2019). Renewable energy in Southeast Asia: Policies and recommendations. Science of the total environment, 670, 1095-1102.

8. Fulton, L., Mejia, A., Arioli, M., Dematera, K., \& Lah, O. (2017). Climate change mitigation pathways for Southeast Asia: CO2 emissions reduction policies for the energy and transport sectors. Sustainability, 9(7), 1160.

9. Behera, S. R., \& Dash, D. P. (2017). The effect of urbanization, energy consumption, and foreign direct investment on the carbon dioxide emission in the SSEA (South and Southeast Asian) region. Renewable and Sustainable Energy Reviews, 70, 96-106.

10. Drobotiuk, O., Osadchuk, V., Shaidetska, V. (2020). Energy Transformation in China: Towards Global Leadership in Renewable Energy. Kitaêznavči doslìdžennâ, 1: 17-26. doi: 10.15407/chinesest2020.01.017 (in Ukrainian)

11. Panchenko, Y. (2018). Modernization of Ukraine's gas transportation system: national and international challenges. Economika Ukrainy, 10(683): 110-126. Available at: https://ir.kneu.edu.ua/bitstream/handle/2010/32822/ EU_18_10_110_uk.pdf?sequence=1\&isAllowed=y (in Ukrainian)

12. Kolechko, D. (2020). Strategic Restructuring of Vietnam's Energy: Compliance with Global Trends. Sciences of Europe, no. 57/57 (2): 21-26. Available at: https://www.europe-science.com/wp-content/uploads/2020/11/VOL2-No-57-2020.pdf (in Ukrainian)

13. Tran, Q. M. (2019). Projection of fossil fuel demands in Vietnam to 2050 and climate change implications. Asia \& the Pacific Policy Studies, 6(2): 208-221. Available at: https://onlinelibrary.wiley.com/doi/pdf/10.1002/app5.274

14. Shem, C. et al. (2019). Potentials and opportunities for low carbon energy transition in Vietnam: A policy analysis. Energy Policy, 134: 110818. doi: 10.1016/j.enpol.2019.06.026

15. Nguyen, H. T., Turksen, U. (2019). The External Effects of the Energy Union Strategy on Trade and Investment in Renewable Energy from the EU to Vietnam: an Initial Assessment. Oil, Gas and Energy Law, vol. (In-press), 30 p. Available at: https://core.ac.uk/download/pdf/228157192.pdf

16. BP. Statistical Review of World Energy June 2020. Available at: http://www.bp.com/statisticalreview

17. World Bank. Available at: https://data.worldbank.org/country/vietnam

18. ASCOPE. Available at: http://www.ascope.org

19. Trade Map. Available at: https://www.trademap.org/Index.aspx

20. The International Renewable Energy Agency (IRENA). Available at: https://www.irena.org/Statistics

21. The Association of Southeast Asian Nations. Available at: https://asean.org/ 